\title{
IMPLEMENTASI NUMBER HEADS TOGETHER SEBAGAI STRATEGI UNTUK MENINGKATKAN STUDENTS ENGAGEMENT PADA SISWA SEKOLAH MENENGAH ATAS
}

\section{IMPLEMENTATION OF NUMBER HEADS TOGETHER AS A STRATEGY TO INCREASE STUDENT ENGAGEMENT IN HIGH SCHOOL STUDENTS}

\author{
${ }^{1}$ Ardhito Faza Akhnaf, ${ }^{2}$ Muhammad Arif Ghadafi Junior, ${ }^{3}$ Nur Hasna Fauziyyah, ${ }^{4}$ Shalahudin \\ Al Ayyubi, ${ }^{5}$ Hazhira Qudsyi \\ Fakultas Psikologi dan Ilmu Sosial Budaya, Universitas Islam Indonesia \\ Corresponding email: ardhitoakhnaf22@gmail.com
}

\begin{abstract}
Learning is an important part of education. The challenges faced in the current learning process to make students actively involved are not easy. One of effort that can be done is to use the Number Heads Together as learning model. Therefore, this study aims to describe the implementation of Number Heads Together as a strategy to increase student engagement in high school students. This research method used a literature review with descriptive data analysis techniques. Based on the results of the analysis of the literature review that has been carried out, it was found that the implementation of the Number Heads Together learning model can increase student engagement which then also has a positive impact on student learning outcomes and achievement.
\end{abstract}

Keywords: Number Heads Together (NHT), students' engagement, High school students, learning model

\begin{abstract}
ABSTRAK
Pembelajaran menjadi salah satu bagian penting dalam pendidikan. Tantangan yang dihadapi dalam proses pembelajaran saat ini untuk dapat membuat siswa terlibat aktif tidaklah mudah. Salah satu upaya yang dapat dilakukan adalah dengan menggunakan model pembelajaran Number Heads Together. Maka dari itu, penelitian ini bertujuan untuk mendeskripsikan implementasi Number Heads Together sebagai strategi untuk meningkatkan students' engagement pada siswa sekolah menengah atas. Metode penelitian ini menggunakan studi literatur dengan teknik analisis data deskriptif. Berdasarkan hasil analisis terhadap studi literatur yang telah dilakukan ditemukan bahwa implementasi model pembelajaran Number Heads Together dapat meningkatkan students' engagement yang kemudian juga membawa dampak positif terhadap hasil belajar dan prestasi siswa
\end{abstract}

Kata Kunci: Number Heads Together (NHT), students' engagement, siswa SMA, model pembelajaran

\section{PENDAHULUAN}

Pembelajaran merupakan suatu bagian yang penting dalam pendidikan di sekolah. Salah satu indikator suksesnya pendidikan di sekolah adalah tercapainya tujuan 
pembelajaran. Tujuan pembelajaran dapat diraih apabila proses belajar dapat berjalan dengan baik yang membuat siswa lebih terlibat aktif untuk mengikuti pembelajaran sehingga ilmu yang disampaikan dapat dipahami dengan baik. Namun pada realitanya kini tantangan pembelajaran untuk membuat siswa dapat selalu terlibat aktif cukup sulit. Ditambah lagi dalam masa pandemi saat ini proses pembelajaran mengalami perubahan total. Pembelajaran yang awalnya berjalan di sekolah secara tatap muka atau luring, berubah drastis menjadi pembelajaran daring atau jarak jauh selama pandemi Covid-19. Tentunya hal tersebut dapat mempengaruhi pembelajaran yang dilakukan oleh siswa. Tidak terkecuali berpengaruh dalam keterlibatan siswa atau students engagement.

Berdasarkan hasil penelitian Kusyanti (2021) terhadap 180 siswa SMA X selama pembelajaran di masa pandemi Covid-19 menunjukkan bahwa terdapat 155 atau 86,2\% responden berada pada kategori students engagement yang rendah dan 25 atau 13,8\% responden yang berada pada kategori students engagement yang sedang. Bahkan dalam penelitian tersebut tidak terdapat siswa yang berada pada kategori students engagement tinggi. Hasil tersebut membuktikan bahwa rendahnya tingkat students engagement yang dialami oleh siswa Sekolah Menengah Atas. Begitu juga penelitian yang dilakukan oleh Mustika dan Kusdiyati (2015) mendapatkan hasil bahwa terdapat 33 siswa (66\%) memiliki students engagement yang rendah dalam belajar. Menurut Mustika dan Kusdiyati (2015) rendahnya students engagement ditampilkan siswa dengan perilaku kurang berusaha dalam belajar, siswa bosan serta tidak memperhatikan pelajaran. Padahal students engagement menjadi salah satu faktor yang memiliki pengaruh besar terhadap keberhasilan belajar siswa di sekolah. Hal tersebut dikarenakan students engagement membawa pengaruh terhadap hasil belajar (Utami \& Kusdiyati, 2019) dan prestasi belajar siswa (Lasantu, 2018).

Salah satu upaya yang dapat dilakukan guna meningkatkan students engagement, yaitu dengan menggunakan model pembelajaran tipe Numbered Heads Together (NHT). Numbered Heads Together merupakan model pembelajaran yang menekankan pada aktivitas siswa. Pembelajaran ini diharapkan agar para siswa dapat menciptakan gagasan yang baru dalam belajar serta meningkatkan keaktifan siswa, kerja sama, dan keberanian untuk mengungkapkan ide-ide dalam proses belajar (Suardini, 2019). Dalam penelitian Efendy (2014), aktivitas yang dilakukan siswa selama penerapan metode Numbered 
Heads Together meningkat dengan baik. Hasilnya adalah partisipasi siswa dalam melakukan pembelajaran meningkat dengan memperlihatkan aktivitas siswa yang secara aktif berinteraksi dengan guru ataupun dengan teman sebaya, memahami materi secara bersama-sama, dan lebih meningkatkan proses belajar-mengajar dalam mencapai tujuan tersebut. Sejalan dengan itu, hasil penelitian Suardini (2019) dan Hanifah (2016) juga menunjukkan bahwa pembelajaran metode Numbered Heads Together dapat meningkatkan aktivitas belajar yang dilakukan oleh siswa dan mengurangi kebosanan selama melakukan proses pembelajaran. Metode pembelajaran Numbered Heads Together dapat membuat siswa lebih aktif bertanya dan melakukan interaksi selama proses pembelajaran.

Atas dasar penjelasan yang menarik sebelumnya, maka penelitian ini bertujuan untuk mendeskripsikan implementasi Numbered Heads Together sebagai strategi untuk meningkatkan students engagement pada siswa SMA. Penelitian ini dilakukan melalui studi literatur pada beberapa penelitian sebelumnya sebab telah banyak penelitian yang menjelaskan terkait penerapan Number Heads Together untuk meningkatkan students engagement pada siswa SMA. Akan tetapi belum ada peneliti yang menghimpun dengan komprehensif dari berbagai hasil penelitian yang telah dilakukan tentang topik tersebut. Berdasarkan identifikasi masalah di atas, maka rumusan masalah dalam penelitian ini yakni, bagaimana implementasi dari Number Heads Together sebagai strategi untuk meningkatkan students engagement pada siswa SMA?

\section{METODE PENELITIAN}

Penelitian ini menggunakan metode studi pustaka. Metode studi pustaka merupakan metode untuk mengumpulkan mengumpulkan berbagai hasil penelitian sebelumnya ataupun sumber tertulis lain yang mendukung pembahasan pada penelitian ini (Sugiyono, 2005). Studi pustaka ini dilakukan dengan mencari sumber literatur melalui portal Google \& Google Scholar. Selanjutnya data yang diperoleh dianalisis dengan menggunakan metode analisis deskriptif. Analisis deskriptif adalah analisis yang dilakukan dengan cara mendeskripsikan data yang telah diperoleh tanpa bermaksud untuk menguji hipotesis ataupun untuk generalisasi (Sugiyono, 2007). 


\section{HASIL PENELITIAN \\ Students Engagement}

Keterlibatan siswa atau students engagement merupakan proses psikologis yang menunjukan perhatian, minat, usaha, dan keterlibatan yang diambil oleh siswa dalam pekerjaan belajar di sekolah (Dharmayana, 2012). Menurut Skinner dan Pitzer (2012, dalam Nurrindar, 2021) keterlibatan siswa atau biasa disebut students engagement adalah kemampuan siswa ketika melibatkan diri pada proses belajar berlangsung. Menurut Reeve dan Tseng (2012, dalam Sa'adah \& Ariati, 2018) terdapat empat aspek dalam student engagement atau keterlibatan siswa, yaitu 1) Agentic engagement, yang diartikan sebagai kontribusi yang konstruktif siswa terhadap instruksi dan tugas yang mereka terima dalam proses belajar mengajar, 2) Behavioral engagement, yaitu usaha atau perlakuan siswa untuk memperhatikan proses pengajaran dan ketekunan dalam mengerjakan suatu tugas serta menaati norma dan aturan untuk menghindari masalah yang akan datang ketika norma dan aturan itu dilanggar, 3) Emotional engagement, yang diwakili oleh emosi positif yang dibawa oleh siswa dalam proses belajar dengan menunjukan ketertarikan dan antusias dalam belajar serta jauh dari emosi negatif. 4) Cognitive engagement, digambarkan oleh penggunaan regulasi diri siswa terkait teknik belajar yang tepat dan mendalam ketika kegiatan belajar dilakukan.

Tentunya ada faktor-faktor lain yang membuat keterlibatan siswa menjadi menurun bahkan sebelum pandemi ini muncul. Menurut Sa (2021) terdapat beberapa faktor yang dapat mempengaruhi students engagement yakni sebagai berikut.

1. Faktor Individu.

Emosi individu menjadi faktor dominan yang memberi kesan pada keterlibatan siswa dalam proses pembelajaran. Individu sendiri akan memberi penilaian tersendiri pada proses belajar mengajar sehingga ketika individu tertarik atau minat pada proses pembelajaran maka nilai keterlibatan siswa akan naik.

2. Faktor Lingkungan.

Faktor lingkungan ini meliputi dukungan orangtua, guru, serta teman sebaya yang akan membuat siswa menjadi lebih percaya diri dan berani untuk melakukan interaksi pada proses pembelajaran berlangsung. Hal 
yang paling utama adalah dukungan dari guru yang terlibat langsung dalam proses pembelajaran di sekolah.

3. Faktor Kontekstual.

Faktor ini berkaitan dengan strategi dalam melakukan pembelajaran dan pengajaran yang memancing siswa untuk melakukan interaksi secara aktif dan terlibat dalam proses belajar mengajar.

4. Faktor Demografi.

Terdapat hasil penelitian menurut Lam et al (2012, dalam Sa, 2021) bahwa keterlibatan murid laki-laki jauh lebih sedikit dibandingkan siswa perempuan. Hal ini dapat diartikan bahwa faktor jenis kelamin bisa mempengaruhi keterlibatan siswa dalam proses belajar mengajar.

Berkaitan dengan hal tersebut, pembelajaran yang kooperatif dapat membantu meraih faktor-faktor yang dapat meningkatkan students engagement. Pembelajaran kooperatif merupakan tipe pembelajaran yang memecah siswa dalam kelompokkelompok kecil untuk bekerjasama guna mencapai suatu tujuan yang diinstruksikan oleh guru (Sugiyanto, 2010). Salam satu pembelajaran kooperatif yang dapat diterapkan adalah Number Heads Together (NHT).

\section{Number Heads Together}

Number Heads Together (NHT) merupakan salah satu model pembelajaran kooperatif struktural yang dirancang untuk memfokuskan pada struktur-struktur khusus, dengan tujuan dapat mempengaruhi pola interaksi siswa dan meningkatkan penguasaan akademik (Sucidamayanti, 2017). Model pembelajaran kooperatif tipe Number Heads Together (NHT) dikembangkan oleh Spencer Kagan (dalam Sucidamayanti, 2017), yang di dalamnya melibatkan siswa dalam menelaah materi yang diberikan pada saat pembelajaran sekaligus mengonfirmasikan terkait pemahaman siswa terhadap materi pelajaran tersebut. Model pembelajaran tipe NHT ini dilakukan dengan cara memberikan nomor pada tiap siswa dalam suatu kelompok, hal tersebut dapat membantu siswa untuk aktif berinteraksi dengan teman kelompoknya, selain itu 
siswa juga terdorong untuk berpikir dalam suatu kelompok dan berani tampil mandiri dalam mengemukakan pendapatnya (Kholis, 2017).

Menurut Ibrahim (dalam Sucidamayanti, 2017), tujuan yang akan dicapai dari pembelajaran kooperatif tipe Number Heads Together di antaranya: a) hasil belajar akademik yang struktural, hasil belajar yang terstruktur dapat meningkatkan kinerja siswa dalam tugas-tugas akademik, b) pengakuan adanya keragaman, dengan model pembelajaran NHT siswa dapat menerima siswa lain dengan berbagai latar belakang, dan c) pengembangan keterampilan sosial, tipe pembelajaran ini bertujuan untuk mengembangkan keterampilan sosial siswa. Lundgren (dalam Ibrahim, 2000) mengemukakan beberapa manfaat dari penerapan model pembelajaran kooperatif tipe Number Heads Together, seperti rasa harga diri meningkat, penerimaan terhadap individu menjadi lebih tinggi, konflik antara pribadi berkurang, pemahaman lebih kompleks dan hasil belajar yang meningkat.

Teori belajar yang mendasari Number Heads Together adalah teori pembelajaran kooperatif yang merujuk pada teori konstruktivisme dan teori belajar sosial Vygotsky (Pramusito, et al, 2016). Paradigma konstruktivisme menjelaskan peran individu dalam membentuk pengetahuan yang diperoleh dari pengalaman, struktur mental dan keyakinan agar dapat menginterpretasikan suatu peristiwa atau objek tertentu. Teori belajar sosial Vygotsky lebih memperhatikan aspek sosial dari pembelajaran. Paradigma Vygotsky menjelaskan bahwa perkembangan kognitif dan pengetahuan diperoleh dari sumber-sumber yang berasal dari lingkungan sosial.

\section{Implementasi Konsep Number Heads Together}

Sebelum menerapkan model pembelajaran kooperatif tipe Number Heads Together, terdapat beberapa tahapan yang perlu diperhatikan (Pramusinto, et al, 2016), antara lain sebagai berikut: 1) Persiapan, dalam tahap pertama guru bertugas mempersiapkan rancangan pelajaran dengan membuat skenario pembelajaran dan lembar kerja siswa yang sesuai, 2) Pembentukan kelompok, guru akan memberikan nomor pada setiap siswa dalam kelompok. Kelompok bersifat campuran yang dibentuk berdasarkan latar belakang sosial, ras, jenis kelamin dan kemampuan belajar, 3) Setiap kelompok harus memiliki buku paket atau panduan, hal tersebut bertujuan untuk 
memudahkan siswa dalam menyelesaikan lembar kerja siswa yang diberikan, 4) Diskusi masalah, pada tahap ini setiap siswa berpikir bersama untuk meyakinkan bahwa setiap dari siswa mengetahui jawaban atas pertanyaan yang tertera dalam lembar kerja siswa, 5) Memanggil nomor anggota dan pemberian jawaban, guru akan menyebut satu nomor secara acak dan para siswa dari tiap kelompok dengan nomor yang sama mengangkat tangan kemudian maju kedepan untuk menyampaikan jawabannya masing-masing, 6) Memberi kesimpulan, dalam tahap ini guru dan siswa berperan bersama untuk menyimpulkan hasil akhir dari jawaban-jawaban yang telah disampaikan.

Model pembelajaran Number Heads Together (NHT) dalam pengaplikasiaannya pada konteks sekolah memiliki kelebihan dan kelemahan. Hamdayama (dalam Pramusinto, et al, 2016) menyebutkan beberapa kelebihan dan kelemahan model pembelajaran tipe Number Heads Together ini. Kelebihan Number Heads Together antara lain, mampu melatih siswa untuk dapat bekerjasama dan menghargai pendapat orang lain, melatih siswa meningkatkan keterampilan berkomunikasi melalui diskusi kelompok, dan melatih siswa untuk terbiasa menjadi tutor sebaya. Sedangkan kelemahan dari model pembelajaran Number Heads Together yakni tidak semua siswa mendapat giliran kesempatan untuk menjawab.

\section{DISKUSI}

Students engagements merupakan suatu komponen psikologis siswa seperti emosional, perilaku, dan kognitif yang berhubungan terhadap keterlibatan dalam proses pembelajaran dan kegiatan akademik di dalam maupun di luar kelas (Gunuc \& Kuzu, 2015). Students engagement menjadi hal penting yang layak menjadi perhatian karena memiliki peran besar dalam pencapaian hasil belajar siswa di dalam maupun di luar kelas (Utami \& Kusdiyati, 2019; Fredricks, Filsecker \& Lawson, 2016). Metode pembelajaran Number Heads Together (NHT) merupakan metode belajar yang kooperatif dan interaktif karena dirancang untuk dapat meningkatkan interaksi siswa dan meningkatkan pemahaman akademik siswa (Sucidamayanti, 2017).

Students engagement dapat ditingkatkan dengan melalui berbagai upaya salah satunya dengan menggunakan model pembelajaran kooperatif. Pembelajaran kooperatif dapat mendorong siswa untuk membangun harga diri dan efikasi diri ketika menjadi 
bagian dalam suatu kelompok belajar ataupun lingkungan kelas yang mendukung proses pembelajaran (Andaritidya, 2014). Salah satu model pembelajaran kooperatif yang dapat diapikasikan untuk meningkatkan students engagement adalah Number Heads Together (NHT (Pramusinto dkk., 2016).

Number Heads Together (NHT) bersifat konstruktivisme yang menuntut siswa aktif untuk berdiskusi di dalam kelompoknya dan memiliki tanggung jawab individu untuk keberhasilan kelompoknya. Number Heads Together juga mendorong siswa untuk mengeksplorasi pengalaman dan pengetahuannya selama berinteraksi dengan sesama siswa, guru, dan lingkungan sekitar (Pramusinto dkk., 2016). Model pembelajaran Number Heads Together itu juga menekankan pada fungsi sosial dan kognitivisme (Pramusinto dkk., 2016). Adanya hal tersebut menuntut siswa untuk aktif bernalar dan berpikir sehingga dapat mengembangkan dan mengubah pemahaman dan persepsi dalam bentuk pengetahuan. Siswa juga dituntut untuk dapat mengkomunikasikan hasil buah pikirannya dengan teman sebaya yang ada di kelompoknya ketika berdiskusi. Alur pembelajaran seperti ini didesain untuk mendorong potensi akademik siswa khususnya siswa yang sebelumnya pasif ketika mengikuti pembelajaran konvensional yang hanya mendengarkan penjelasan dari guru kemudian dengan adanya model pembelajaran Number Heads Together siswa lebih banyak terlibat dalam pembelajaran.

Berdasarkan hasil analisis kajian literatur tambahan, menyatakan bahwa Number Heads Together juga dapat membantu untuk meningkatkan aktivitas pembelajaran siswa sehingga siswa tidak gampang merasa jenuh selama belajar (Efendy, 2014; Suardini, 2019; Hanifah, 2016). Bahkan dalam hasil penelitian lain, Number Heads Together juga telah terbukti dapat membawa dampak positif bagi siswa SMA yang diterapkan dalam berbagai mata pelajaran, yakni seperti meningkatkan aktivitas dan prestasi belajar siswa pada materi hidrokarbon (Laksono dkk, 2014), meningkatkan kreativitas belajar biologi siswa (Maya dkk., 2019) \& meningkatkan hasil belajar kimia siswa (Sulfiani, 2016). Selain itu, keaktifan siswa dalam mengikuti model pembelajaran Number Heads Together mampu meningkatkan keterampilan komunikasi siswa (Wardah \& Nasrudin, 2020; Adnyana \& Runimeirati, 2021). Tentunya semua dampak positif Number Heads Together yang diperoleh tersebut melibatkan students engagement yang tinggi di setiap kegiatan pembelajaran. 
Review hasil penelitian-penelitian sebelumnya berkaitan dengan berbagai manfaat Number Heads Together dapat menjadi gambaran bahwa Number Heads Together dapat menjadi solusi nyata untuk dapat meningkatkan students engagement khususnya pada kalangan siswa SMA. Selain itu, hal tersebut juga menjadi kebaruan dalam penelitian ini sebab belum ada penelitian sebelumnya yang mengkaji dan merangkum hasil-hasil penelitian terdahulu terkait Number Heads Together \& students engagement pada siswa SMA.

\section{KESIMPULAN DAN SARAN}

Berdasarkan hasil analisis pembahasan yang telah dilakukan, dapat disimpulkan bahwa implementasi Number Heads Together dapat menjadi salah satu upaya untuk dapat meningkatkan students engagement pada siswa SMA. Dengan tingginya students engagement dalam pembelajaran, maka hal ini akan membawa pengaruh positif terhadap hal-hal lain seperti keterampilan komunikasi, hasil belajar, dan prestasi belajar siswa. Hasil penelitian ini dapat menjadi saran bagi guru untuk dapat menerapkan Number Heads Together dalam proses pembelajaran supaya dapat membantu untuk meningkatkan students engagement.

\section{DAFTAR PUSTAKA}

Adnyana, P. P., \& Runimeirati, R. (2021). Pembelajaran Number Head Together (NHT) pada keterampilan berbicara siswa. Indonesian Collaboration Journal of Community Services, 1(4), 230-235.

Andaritidya, A. (2014). Efektivitas pembelajaran kooperatif stad dalam meningkatkan perilaku keterikatan siswa sd dalam pelajaran matematika. Jurnal Psikologi, 7(2).

Dharmayana, I. W. (2012). Keterlibatan siswa (student engagement) sebagai mediator kompetensi emosi dan prestasi akademik. JURNAL PSIKOLOGI, 39(1), 76-94.

Efendy, G. (2014). Penggunaan model pembelajaran kooperatif tipe numbered heads together dalam pembelajaran IPS untuk meningkatkan keterampilan partisipasi social siswa kelas V SDN Putat Gede II Surabaya. JPGSD. 2(2), 1-11.

Fredricks, J. A., Filsecker, M \& Lawson, M.A. (2016). Student engagement, context, and adjustment: Addressin definitional, measurement, and methodological issues. Learning and instruction.

Gunuc, S \& Kuzu, A. (2015). Student engagement scale: Development, reliability and validity. Assessment \& Evaluation in Higher Education, 40(4), 587-610.

Hanifah, M. (2016). Improving student engagement in writing using numbered heads together (NHT) (a classroom action research in class VII B of SMP Negeri 16 Surakarta in academic year of 2015/2016). Skripsi. 
Kholis, N. (2017). Penerapan Model Pembelajaran Numbered Head Together Untuk Meningkatkan Hasil Belajar Siswa. Iqra': Jurnal Kajian Ilmu Pendidikan, 2(1), 6988.

Kusyanti, R. N. T. (2021). Hubungan antara stres akademik dan student engagement siswa sma pada masa pandemi Covid-19. Ideguru: Jurnal Karya Ilmiah Guru, 6(3), 315-320.

Laksono, P. J. (2014). Penerapan model pembelajaran numbered head together (NHT) dengan media handout sebagai upaya peningkatan aktivitas dan prestasi belajar siswa pada materi pokok hidrokarbon kelas X. 2 ICT 2 SMA Muhammadiyah 1 Karanganyar tahun pelajaran 2012/2013. Jurnal Pendidikan Kimia (JPK), 3(1), 80-85.

Lasantu, M. (2018). Upaya meningkatkan hasil belajar siswa dengan menggunakan model pembelajaran Number Head Together (NHT) pada kelas XI IPA-5 di SMA Negeri 1 Gorontalo. Skripsi. Universitas Negeri Gorontalo

Maya, A., Ginting, N., \& Tuah, S. (2019). Upaya meningkatkan kreativitas belajar biologi siswa melalui penerapan model pembelajaran kooperatif tipe Number Head Together (NHT) di MAN Siabu. PeTeKa, 2(1), 1-8.

Mustika, R.A., \& Kusdiyati,S. (2015). Studi deskriptif student engagement pada siswa kelas XI IPS di SMA Pasundan 1 Bandung. Prosiding Penelitian Sivitas Akademika Unisba (Sosial Humaniora) Psikologi, Gelombang 2, Tahun Akademik 20142015. http://karyailmiah.unisba.ac.id/index.php/psikologi/article/view/1204.

Nurrindar, M., Wahjudi, E. (2021). Pengaruh self-efficacy terhadap keterlibatan siswa melalui motivasi belajar. Jurnal Pendidikan Akuntansi (JPAK), 9(1), 140-148.

Pramusinto, N. D., Wahyuni, S., \& Totalia, S. A. (2016). Penerapan Number Heads Together Untuk Meningkatkan Students Engagement Dan Hasil Belajar SMKN 3 Surakarta. Jurnal Pendidikan Bisnis dan Ekonomi, 2(1), 1-18.

Pramusinto, N., Wahyuni, S., \& Totalia, S. A. (2016). Penerapan Number Heads Together untuk meningkatkan students'engagement dan hasil belajar SMKN 3 SURAKARTA. Jurnal Pendidikan Bisnis dan Ekonomi, 2(1).

Sa, S. L. Y., Surat, S. (2021). Faktor dan kesan keterlibatan pelajar terdahap pencapaian akademik (factor and implication of student engagement on achievement). International Journal of Advanced Research in Islamic Studies dan Education (ARISE), 1(3), 81-91.

Sa'adah, U., Ariati, J. (2018). Hubungan antara student engagement (keterlibatan siswa) dengan prestasi akademik mata pelajaran matematika pada siswa kelas xi sma negeri 9 semarang. Jurnal Empati, 7(1), 69-75.

Suardini, A. A. O. S. (2019). Penerapan model pembelajaran kooperatif tipe numbered heads together (NHT) untuk meningkatkan aktivitas dan hasil belajar rias wajah khusus untuk kreatif (cikatri). Journal of Education Action Research. 3(1), 45-52.

Sucidamayanti, N. P. W. (2017). Penerapan Model Pembelajaran Kooperatif Tipe Numbered Heads Together (Nht) Untuk Meningkatkan Hasil Belajar Ips. Journal of Education Action Research, 1(3), 184. https://doi.org/10.23887/jear.v1i3.12683.

Sugiyono. 2005. Memahami penelitian kualitatif. Bandung: CV Alfabeta.

Sugiyono. 2007. Metode penelitian kuantitatif kualitatif dan R\&D. Bandung: CV Pustaka Setia. 
Sulfiani, R. (2016). Penerapan model pembelajaran kooperatif tipe Numbered Head Together (NHT) untuk meningkatkan hasil belajar kimia siswa kelas XI IPA1 SMA Negeri 3 Watampone (studi pada materi pokok struktur atom, sistem periodik unsur dan bentuk molekul). Chemica: Jurnal Ilmiah Kimia dan Pendidikan Kimia, 17(1), 1-13.

Utami, A. D., \& Kusdiyati, S. (2019). Hubungan antara student engagement dengan prestasi belajar pada siswa kelas XI di Pesantren Persatuan Islam No. I Bandung. Prosiding Psikologi, 1(2). http://dx.doi.org/10.29313/.v0i0.1006.

Wardah, D., \& Nasrudin, H. (2020). Penerapan model pembelajaran kooperatif tipe NHT (Number Head Together) untuk melatihkan keterampilan komunikasi siswa SMA kelas XI pada materi pokok asam basa. UNESA Journal of Chemical Education, 9(1), 127-132. 